\title{
Vascular Malformation
}

National Cancer Institute

\section{Source}

National Cancer Institute. Vascular Malformation. NCI Thesaurus. Code C112117.

A cong enital abnormality of the arteries and veins, lymph vessels or veins and lymph vessels. 